\title{
POLA PEMBINAAN MUALLAF DI KOTA MANADO
}

\section{The Pattern of Muslim Convert Guidance in Manado}

\author{
Muhammad Irfan Syuhudi
}

\author{
Balai Litbang Agama Makassar \\ Alamat: A.P. Pettarani No 72 Makassar \\ Email:m_ippank@yahoo.com
}

Naskah diterima tanggal 2 Agustus 2012. Naskah direvisi tanggal 8 September 2012. Naskah disetujui tanggal 2 Oktober 2013

\begin{abstract}
Abstrak
Pembinaan muallaf di Kota Manado menjadi sesuatu yang menarik untuk diperbincangkan. Apalagi, Kota Manado merupakan daerah yang kebanyakan penduduknya beragama non Islam. Penelitian ini bertujuan untuk mendeskripsikan pola pembinaan muallaf di Kota Manado, mengetahui hambatanhambatannya, dan mendeskripsikan keterlibatan kementerian agama dalam membina muallaf. Penentuan informan dilakukan secara purposive, yakni para muallaf dan orang-orang yang terlibat dalam pembinaan muallaf. Teknik pengumpulan data melalui wawancara mendalam dan observasi, sedangkan analisis data secara deskriptif kualitatif. Hasil penelitian menemukan, pembinaan muallaf di Kota Manado sejauh ini belum mendapat perhatian serius dari pemerintah setempat (kementerian agama provinsi dan kota). Pembinaan muallaf lebih banyak dilakukan oleh ormas, yayasan (lembaga pendidikan), dan individu-individu. Karena itu, kementerian agama seharusnya melibatkan diri dalam proses pembinaan muallaf, termasuk bekerja sama dengan ormas atau orang-orang yang fokus melakukan pembinaan.
\end{abstract}

Kata kunci: muallaf, pembinaan muallaf, ormas, indvidu

\begin{abstract}
The guidance for Muslim converts in Manado has become the interesting discourse. Moreover, the people in Manado are mostly non-Muslims. The research aimed at describing the guidance pattern for Muslim converts in Manado, identifying the obstacles, and describing the involvement of Religion Ministry in the guidance activity. The informants were the Muslim converts and the involved people in the guidance in which they were chosen purposively. The techniques of data collection were in-depth interview, and observation, and then the collected data were analyzed qualitatively. Based on the result of the research, it was found that the guidance for Muslim converts has not got serious attention yet from the local government (The Religion Ministry neither in a province level nor regency level). The guidance was mostly carried out by the organizations, the educational institutions, and individuals. Therefore, the Ministry Religion should be involved in the guidance activity which is included to collaborate with organizations or people who have attention to conduct the guidance.
\end{abstract}

Keywords: muslim converts, the Guidance for muslim converts, organizations, individual

\section{PENDAHULUAN}

$\mathrm{P}$ ersoalan agama merupakan hak individu manusia. Dalam arti kata, manusia bebas memeluk agama apa saja yang menurut mereka paling benar, sesuai yang diakui negara Indonesia (Islam, Kristen, Katolik, Hindu, Budha, dan Khonghucu). Hanya saja, sebagian besar orang yang beragama itu memeluk "agama warisan" atau agama yang dianut oleh orang tuanya. Misalkan orang tuanya Islam, praktis anaknya juga akan beragama Islam, mengikuti agama orang tuanya. Padahal, setiap orang memiliki hak istimewa untuk memlilih agamanya masing-masing, tetapi 
tidak semua orang menggunakan hak istimewanya tersebut. Namun, dalam beberapa kasus, ada juga orang memilih agama yang berbeda dari agama yang dianut orang tuanya dengan alasan tertentu.

Di Manado, jumlah muallaf diperkirakan merangkak naik setiap tahun. Hal ini diungkapkan Drs. Hartono Bawenti. Kepala Kantor urusan Agama (KUA) Kecamatan Wenang, Manado ini, mengemukakan, dalam setahun, ada 20 sampai 30 orang berpindah ke Islam di kota berjuluk Nyiur Melambai ini. Ini hanya satu kecamatan saja sementara di Manado itu ada sembilan kecamatan. Umumnya perempuan dengan alasan ingin menikah. Sayang, perpindahan agama itu hanya menggembirakan dari segi kuantitas dan belum sampai kepada kualitas ketaatan beragama. Mengapa? Ternyata, di antara mereka itu (perempuan) masih ada yang akhirnya memilih balik ke agama asalnya setelah gagal mengarungi bahtera rumah tangga. Setelah bercerai, orang tua atau keluarga dari pihak perempuan seringkali mengajaknya untuk kembali ke agama asalnya dan yang bersangkutan pun mengiyakan.

Di samping itu, ada juga perempuan, dalam hal ini istri, yang ternyata belum tahu mengaji dan menulis Al-Quran, serta memiliki alat perlengkapan shalat. Padahal, mereka itu telah lama memeluk Islam. Kuat dugaan, mereka tidak mendapat bimbingan langsung dari suaminya setelah menikah. Sang suami tampaknya tidak berinisiatif memasukkan istrinya dalam kelompok pengajian di masjid maupun kelompok pengajian lain di Manado.

Dalam kasus lain, ada juga muallaf yang ternyata tidak mau belajar Islam. Setelah memeluk Islam, pemahamannya tentang Islam bersifat stagnan atau berjalan di tempat. Padahal, muallaf itu ibarat "bayi", yang harus dilayani, dibina, dan diperhatikan segala macam kebutuhan spiritualnya. Namun, sebaliknya, ada juga muallaf yang kelihatan justru lebih alim ketimbang orang yang sejak lahir memeluk Islam. Malah, di antara mereka itu ada yang telah bergelar haji dan ikut membina orang-orang yang ingin belajar Islam. Jadi, memang dibutuhkan kesabaran dalam melakukan pembinaan terhadap muallaf. Ini pula yang menjadi salah satu tugas penting kementerian agama, yakni peningkatan kualitas kehidupan beragama dan peningkatan kerukunan umat beragama, seperti yang terdapat dalam salah satu poin rencana strategi.

\section{Teori Pembinaan Keagamaan}

Pembinaan adalah kegiatan terorganisir yang dilakukan seseorang atau lembaga untuk membantu kelompok tertentu (yang dianggap kelemahan tertentu) mendapatkan pengetahuan tentang obyek tertentu. Berdasarkan hasil penelitian, pembinaan di sini dilakukan oleh tokoh agama, organisasi keagamaan, dan lembaga keagamaan. Capaian utamanya adalah terjadinya perubahan sikap dan orientasi dari kelompok yang dibina itu.

Dalam konteks pembinaan muallaf, tema pembinaan berkaitan dengan penguatan spiritual para muallaf untuk lebih memahami keislaman yang berarti penguatan keimanannya, yang pada akhirnya memunculkan kepercayaan dalam dirinya untuk beraktualisasi sebagai manusia dengan identitas baru. Yang dimaksud muallaf dalam penelitian ini adalah semua orang yang beralih agama dari agama tertentu (termasuk agama lokal) ke dalam Islam, tanpa dibatasi durasi waktunya.

Perpindahan agama seseorang ke agama lain disebut konversi. Konversi ini juga secara etimologi berarti tobat, pindah, atau berubah. Sementara dalam bahasa Inggris dikatakan conversion, yang berarti berubah dari suatu keadaan atau dari satu agama ke agama lain (Mulyono, 2007:43). Dalam bahasa Jalaluddin (2001: 261:265), konversi adalah orang yang sudah bertobat dan kemudian menjadi lebih taat (dengan pilihan agama barunya itu).

Konversi agama merupakan suatu peristiwa penting dalam kehidupan seseorang. Menurut Paloutzian (1996: 140), konversi agama akan membuat seluruh kehidupan seseorang berubah selama-lamanya, karena pada dasarnya konversi agama merupakan perubahan mendasar dan penataan ulang identitas diri, makna hidup juga aktivitas seseorang. Ketika seseorang melakukan konversi agama, maka individu diharapkan bisa meninggalkan sebagian atau bahkan seluruh nilai, keyakinan, dari sistem nilai dan aturan yang lama. Di saat yang sama, individu diharapkan mampu mengetahui tata nilai, sistem perilaku dari agama yang baru dianut, sekaligus menyesuaikan diri, melakukan aktivitas danpola perilaku yang sesuai. Melakukan konversi agama berarti belajar dan beradaptasi dengan banyak hal tentang berbagai hal yang baru.

Heirich (dalam Jalaluddin, 2001: 260) mendefinisikan konversi agama sebagai suatu tindakan yang dilakukan oleh seseorang atau 
sekelompok orang masuk atau berpindah ke suatu sistem kepercayaan atau perilaku yang berlawanan dengan kepercayaan sebelumnya. Definisi ini tampaknya lebih mengedepankan adanya proses perpindahan keyakinan ke agama lain yang berbeda dengan agama yang dianut sebelumnya.

Pengertian konversi agama yang diberikan James (2004: 280) yaitu peristiwa menjadi terlahir kembali (regenerated), menerima rahmat, mendapatkan pengalaman keagamaan, memperoleh kepastian, yang menunjukkan suatu proses baik yang berlangsung bertahap maupun cepat. Ketika pribadi sebelumnya mengalami keterbelahan dan sadar bahwa dirinya rendah, salah, dan tidak berbahagia, menjadi menyatu dan merasa percaya diri, benar dan berbahagia, sebagai akibat menguatnya keyakinan terhadap realitasrealitas keagamaan. Pargament (1997: 248), menilai konversi agama sebagai semangat untuk kembali mengatur kehidupan pribadi, pengalaman berharga yang mengubah secara drastis 'diri' menjadi mengidentifikasikan diri dengan sesutu yang sakral.

Secara administratif, Manado terbagi ke dalam 9 (sembilan) wilayah kecamatan dan 87 kelurahan/ desa, serta memiliki luas wilayah sebesar 157,26 $\mathrm{km} 2$. Penduduk berdasarkan kecamatan di Kota Manado berjumlah 410,481 jiwa, yakni masingmasing Kecamatan Malalayang dengan jumlah penduduk 54.959 jiwa, Sario berjumlah 23.189 jiwa, Wanea berjumlah 56.962 jiwa, Wenang (32.796 jiwa), Tikala (69.734 jiwa), Mapanget (53.194 jiwa), Singkil (46.721 jiwa), Tuminting (52.089 jiwa), dan Bunaken (20.828 jiwa) (Kota Manado dalam Angka, 2011).

Berdasarkan agama, Kota Manado dihuni mayoritas penduduk beragama Kristen, yakni berjumlah 290.665 jiwa. Sementara agama Islam berjumlah 175.569 jiwa, Katolik berjumlah 30.275 jiwa, Buddha, 6.436 jiwa, Hindu berjumlah 2.592 jiwa, dan Khonghucu 600 jiwa (Kemenag Kota Manado, 2011).

\section{METODE PENELITIAN}

Penentuan informan dilakukan dengan purposive, yang terdiri atas muallaf dan kelompok atau individu yang membina muallaf. Informan yang dipilih adalah mereka yang mudah diajak bicara, mengerti tentang informasi yang peneliti butuhkan, dan yang senang diajak bekerja sama (Suwardi: 2006: 121).
Data pada penelitian ini dibagi atas dua, yakni data primer dan data sekunder. Data primer diperoleh dari pengamatan (observasi) langsung di lapangan dan wawancara mendalam (indept interview). Untuk pengamatan digunakan teknik berperanserta, yakni memasuki wilayah penelitian untuk mengungkap data hingga mendetail (Suwardi: 2006: 138, Lexy: 2010: 177). Sedangkan wawancara mendalam atau wawancara etnografi, meminjam istilah Suwardi (2006: 168), saya berusaha melakukan dengan santai dan informal, sehingga ada keterbukaan antara peneliti dan diteliti. Ini juga dimaksudkan agar orang yang diwawancarai tidak merasa sedang diwawancarai (Lexy: 2010: 187).

Analisis data dilakukan secara deskriptif etnografik, yakni berusaha mendeskripsikan subjek penelitian dan cara mereka bertindak dan berkatakata. Analisis data juga dilakukan dengan menelaah seluruh data yang tersedia dari berbagai sumber, yaitu hasil wawancara, catatan lapangan, dokumendokumen, dan lain-lain. Setelah itu mereduksi data, memaparkan data dan simpulan melalui pelukisan dan verifikasi (Suwardi: 2006: 176).

\section{PEMBAHASAN \\ Muallaf di Manado: Yang Melatari Konversi Agama}

Banyak faktor yang menyebabkan seseorang melakukan konversi ke agama Islam. Namun, secara umum, hanya ada tiga faktor yang paling dominan, yakni mendapatkan petunjuk Ilahi/hidayah, faktor sosial, dan faktor psikologis (Jalaluddin, 2001: 261265).

Di Manado, motivasi orang untuk melakukan konversi agama pada umumnya karena ingin menikah. Menurut Kepala KUA Wenang, Hartono Bawenti, setiap tahun ada 20 sampai 30 muallaf yang mendaftar ke KUA untuk menikah. Sebagian besar perempuan, mengikuti agama suaminya. Pada saat mendaftarkan diri ke KUA, mereka diharuskan menunjukkan surat Pernyataan Memeluk Islam. Dalam surat pernyataan yang disertai foto itu, ada empat orang yang bertandatangan. Selain orang bersangkutan (muallaf), di situ juga bertandatangan imam masjid, saksi pertama dan saksi kedua. Umumnya, para muallaf yang ingin menikah ini perempuan berusia rata-rata 18 hingga 25 .

Selain menikah, ada juga yang memeluk Islam karena proses pembelajaran. Sebelum memeluk Islam, orang tersebut terlebih dulu ingin mengenal 
Islam, baik melalui pembacaan buku-buku Islam, membaca terjemahan Al-Quran, maupun berdiskusi dengan orang muslim atau temannya yang duluan muallaf. Dari proses pembelajaran inilah, mereka akhirnya mantap memilih Islam.

\section{Aktor di Belakang Layar Pembinaan Muallaf}

Kasi V Supervisi dan Evaluasi Kemenag Provinsi Sulawewsi Utara, Abdul Rahim, mengemukakan, ada tiga organisasi Islam (ormas) besar di Manado. Mereka adalah Muhammadiyah, NU, dan Syarikat Islam (SI) (wawancara di Manado, 18 Juni 2012).

Sayangnya, ketiga ormas besar itu secara kelembagaan memang belum mempunyai program khusus membina muallaf. Salah satu kendalanya adalah tidak adanya dana. Sementara, mereka yang terjun khusus membina muallaf dan bergabung di salah satu ormas Islam itu tak lain adalah sebagai bentuk panggilan jiwa dan tanggungjawab moral untuk membantu umat Islam dalam pemberantasan buta huruf Al-Quran. Itu artinya, pembinaan muallaf di Kota Manado tidak didominasi oleh salah satu ormas Islam tertentu.

Kalau pun ada, orang-orang yang masuk ke dalam kepengurusan tiga ormas Islam itu hanya melibatkan diri secara personal dalam kelompok keagamaan tersebut. Atau, ada juga yang secara individual memang membina muallaf dan tidak bergabung dengan salah satu lembaga keagamaan. Pada lembaga keagamaan, misalnya ada Kerukunan Wanita Islam (KWI) Manado. Di dalam kepengurusan KWI, ada yang berasal dari NU (Muslimat NU), Aisyiah (perempuan Muhammadiyah), Syarikat Islam, dan BKMT. Selain itu, ada juga Yayasan Assalam melalui majelis taklimnya, Kajian Kristologi Anti Pemurtadan (KAKAP), dan Barisan Pemuda/Remaja An-Nahl. sementara pembinaan individual dilakukan oleh Kyai H. Abdul Wahab Abdul Gafar, LC.

Berikut ini lembaga keagamaaan dan individual yang intensif melakukan pembinaan muallaf di Manado:

\section{Kerukunan Wanita Islam (KWI) Manado}

Ada hal menarik dari KWI ini. Tentu saja, karena semua pengurusnya perempuan. Ketua KWI Manado yang dinahkodai Dra Hj. S. Rachim Mokoginta ini merupakan organisasi independen yang pengurusnya berasal dari berbagai macam latar belakang organisasi masyarakat Islam. Ada Muhammadiyah, NU, Syarikat Islam, dan BKMT.
Secara singkat, awal mula berdirinya KWI adalah sebagai bentuk kegelisahan dari kaum perempuan yang melihat begitu mirisnya kehidupan umat Islam, terutama perempuan, di tengah-tengah mayoritas kristianidiSulawesi Utara pada umumnya, dan Manado pada khususnya. Apalagi, saat itu, banyak perempuan Islam yang sama sekali tidak mengetahui baca tulis Al-Quran. Atas kegelisahan tersebut, beberapa perempuan merasa terpanggil untuk melakukan perlawanan, setidaknya mereka bertekad memberantas buta aksara Al-Quran. Maka, setelah beberapa kali bertemu dan menggagas ideide cemerlang, pada 13 Juli 1970 terbentuklah KWI di Provinsi Sulawesi Utara. Tokoh dibalik berdirinya KWI ini ada tiga orang, yaitu Ny. Kartawinata Abas, Ny. Hj. Sariden Masloman, dan Ny. Hj. R. Bemba Arbie. Namun, sebelum membentuk KWI ini, ketiga perempuan tersebut terlebih dulu meminta persetujuan MD Kartawinata, yang saat itu menjabat Ketua Badan Antar Umat Beragama Sulawesi Utara. Setelah terbentuk, KWI mengambil lokasi di masjid Al-Ikhlas Kecamatan Wanea, yang ketika awal terbentuknya hanya memiliki 15 orang anggota.

Untuk memperkuat posisi organisasi ini, mereka lalu menghadap Kakanwil Kemenag Sulawesi Utara (dulu Kakanwil Departemen Agama), yang selanjutnya KWI berada di bawah naungan Kemenag Sulawesi Utara. KWI pertama kali terbentuk hanya berpusat di Manado dan bersifat lokal. Tetapi, pada tahun 1980-an, anggota KWI mulai banyak berasal dari kampung-kampung di seluruh Sulawesi Utara. Mereka mengadakan pengajian dari masjid ke masjid. Waktu itu, masjid di Manado masih sedikit. Dari masjid ke masjid kemuadian keluar masuk kampung di pinggiran Manado untuk berdakwah. Dibentuknya wadah ini untuk meningkatkan ilmu pengetahuan mengenai Islam khususnya ibu-ibu.

Selain semuanya perempuan, pengurus dan anggota KWI juga berasal dari pelbagai golongan sosial. Artinya, pengurus yang masuk ke dalam kepengurusan KWI tidak dibenarkan membawa nama organisasi. Di sini, mereka betul-betul murni membawa pribadi masing-masing dengan tujuan menggiatkan dakwah islamiyah (amar ma'ruf nahi munkar yang berpedoman pada Al-Quran dan Sunnah). Apalagi, KWI ini merupakan organisasi yang independen. Saat ini, di Manado mempunyai 80 ranting (masjid). Jumlah anggota di tiap-tiap ranting itu tergantung dari jamaah masjid yang bersangkutan. 
Dengan terbentuknya KWI, mereka ingin menunjukkan bahwa perempuan di Manado sebenarnya bisa pula ikut menyumbangkan pikiran dan tenaga untuk kepentingan umat Islam. Namun, dalam hal ini, perlu ditegaskan bahwa cikal bakal terbentuknya KWI itu bukanlah untuk menandingi lembaga-lembaga keagamaan yang didominasi lakilaki.

\section{Yayasan Assalam}

Yayasan Assalam yang terletak di Kelurahan Bailang, Kecamatan Bunaken, cukup populer di Kota Manado, dan bahkan di Sulawesi Utara. Yayasan ini gaungnya malah terdengar sampai di Jakarta. Assalam kini menaungi tujuh unit, yakni panti asuhan, pesantren, majelis taklim, poliklinik, Siam (Studi Islam Assalam), Ikatan Pemuda Remaja Islam (IPRA), BMT (Baitul Mal/ekonomi), Taman kanak-kanak Islam, An-Nahl. Di luar unit ini, ada yang namanya KAKAP (Kajian Kristologi Anti Pemurtadan). Khusus untuk Majelis Taklim, Yayasan Assalam membina 48 majelis taklim di 39 desa di Manado. Di setiap majelis taklim itu, terdapat tiga sampai lima orang muallaf.

Sebelum berbentuk yayasan, lembaga berada di bawah naungan Karya Islamiah dan pendirinya berasal dari orang-orang Dinas Pancakya yang concern terhadap umat Islam yang kebanyakan tidak bisa mengaji. Lambat laun, Assalam melakukan evolusi, terlebih setelah melihat kondisi sosial masyarakat Islam yang perlu mendapat uluran tangan.

Setelah membuat program mengentaskan buta aksara Al-Quran, Assalam kemudian resah melihat banyak anak-anak yang terlantar. Tak lama berselang, maka dibentuklah panti asuhan. Lamalama, mereka berpikir anak-anak panti asuhan ini akan di sekolahkan ke mana? Maka dibentuklah pesantren. Begitu seterusnya hingga menaungi tujuh unit. Sementara, majelis taklim yang kini berjumlah 39 desa dan dibimbing setiap Minggu oleh sarjana dan magister, merupakan pembinaan umat di luar internal.

Pada awal-awal berdirinya memang berada di bawah naungan departemen agama (kementerian agama). Tetapi kemudian mereka memilih berpisah dan mendirikan yayasan dengan pertimbangan untuk menghindari apabila kakanwil kemenag suatu saat nanti dijabat oleh orang non Islam. Meski begitu, Assalam masih bekerja sama dengan kemenag, utamanya dalam pembinaan umat. Kalau khusus pembinaan muallaf, tidak ada hubungannya dengan kemenag karena KAKAP itu murni program dari yayasan.

\section{KH. Abdul Wahab Abdul Gafar, LC (Pembinaan Individual)}

KH. Abdul Wahab Abdul Gafar, LC adalah Ketua Majelis Ulama Indonesia (MUI) Kota Manado periode 2011-2016, penyuluh agama Pegawai Negeri Sipil Kemenag Kota Manado, serta imam Masjid Arrahmah, Kelurahan Banjer. Menurutnya, dia merasa berkewajiban membina umat Islam, termasuk para muallaf. Apalagi, dia selalu memegang teguh prinsip bahwa, di dalam konsep pendidikan Islam itu tidak ada kata berhenti untuk belajar Islam (dari ayunan sampai ke liang kubur). Belajar dan terus belajar. Konsep inilah yang dia terapkan dalam membina umat Islam. Karena itu, Kyai Wahab yang sudah menjadi imam sekitar 25 tahun, kemudian membentuk Majelis Taklim AlKhaerat di Masjid Arrahmah. Inilah majelis taklim pertama yang dibentuk, yang kini telah berusia 22 tahunan. Pembinaan umat ini merupakan salah satu program Masjid Arrahmah dan dia sendirilah yang memprakarsainya. Dari sini, kemudian lahir lagi beberapa majelis taklim seperti Al-Hikmah, Arrahmah, Nurul Jum'ah, dan Forum Silaturrahmi Haji Banjer dan sekitarnya, yang kini berganti nama menjadi Forum Silaturrahmi Haji Mas'aril Haram. Di setiap kelompok pengajian tersebut terdapat juga muallaf. Dalam membina majelis taklim, Kyai Wahab dibantu tujuh orang ustadz dan ustadzah. Dua di antaranya perempuan. Di antara muallaf yang dibina itu, yang terbanyak adalah perempuan asal Minahasa. Kini, di antara muallafnya itu banyak yang telah khatam Al-Quran dan juga bergelar hajjah.

Lokasi pembinaan di lakukan di tiga tempat, yaitu masjid, sekolah, dan rumah ke rumah. Majelis Taklim Al-Hikmah, Arrahmah, dan Nurul Jumah dibina di masjid, Al-Khaerat di bina di Madrasah Ibtidaiyah Waliyah Al-Khaerat Mayora, Banjer. Sedangkan pembinaan forum haji dilakukan di rumah-rumah anggotanya secara bergiliran.

Selain itu, Kyai Wahab juga kerap kali melakukan pengislaman, baik dilakukan di rumahnya maupun di Masjid Arrahmah. Sebelum melakukan pengislaman, dia meminta orang tersebut mematuhi atau mentaati persyaratan yang dia tetapkan. Bagi laki-laki, dia terlebih dulu harus dikhitan (sunat) karena merupakan salah satu cara dari proses pembersihan diri. 
Setelah dikhitan, calon muallaf itu akan dimandikan. Hal ini berlaku bagi laki-laki dan perempuan. Setelah melalui semua proses ritual tersebut, calon muallaf selanjutnya diajarkan mengucapkan syahadat sebagai pertanda resminya dia memeluk Islam. Setelah itu, muallaf diberikan sertifikat yang ditandatangani oleh imam masjid.

\section{Pola Pembinaan Muallaf Pembinaan Struktural}

Metode yang digunakan lembaga atau kelompok keagamaan maupun individual dalam membina muallaf hampir seragam. Umumnya, semua membagi pembinaan itu ke dalam tiga tahap, yaitu pengajian (iqra), tata cara shalat dan bacaannya, dan pengetahuan umum Islam. Tahap pertama adalah pengajian (Iqra satu dan seterusnya hingga tajwid); kedua, tata cara shalat dan bacaan doa-doa shalat; dan ketiga adalah pengetahuan umum tentang Islam, seperti akidah akhlak, tauhid, fiqih, dan sebagainya.

Sementara pengaturan jadwalnya juga bervariasi, yakni enam hari berturut-turut, sepekan dua kali atau tiga kali, sekali sepekan, dan dua kali sebulan. Tempatnya pun berbeda-beda. Ada di masjid-masjid, sekolah, rumah ke rumah, dan rumah pribadi (pembina). Mereka memilih masjid lantaran jumlah jamaahnya tergolong banyak. Apalagi, setelah mengaji biasanya diselingi pula ceramah agama yang dibawakan ustadz atau ustadzah. Sedangkan, pembinaan dari rumah ke rumah itu sebenarnya untuk membina secara halus orang yang "menolak" bergabung masuk kelompok pengajian. Masalahnya, ada juga orang (dewasa) yang malu kalau dirinya ditahu belum tahu mengaji.

\section{Pembinaan Kultural}

Selain diajarkan mengaji, tata cara shalat, dan akidah, muallaf juga dibina ekonominya. Di antara muallaf itu ada juga yang dikategorikan menengah ke bawah. Mereka ini berprofesi di sektor informal seperti tukang ojek, kuli bangunan, sopir angkutan kota, dan malah ada yang belum punya pekerjaan tetap alias pengangguran. Alhasil, ada seorang perempuan yang meskipun telah beberapa tahun memeluk Islam, namun ternyata belum memiliki peralatan shalat (mukena). Itu berarti, selama itu pula dia diduga tidak mengerjakan shalat. Karena itu, untuk membantu keuangan para muallaf yang digolongkan kurang mampu itu, maka dilakukan pula pembinaan secara ekonomi. Caranya, para muallaf itu diberikan modal untuk membuka usaha seperti misalnya membuka warung, dan sistem pembagian hasilnya dengan cara subsidi silang. Cara seperti inilah yang dilakukan Majelis Taklim Assalam.

\section{Hambatan Pembinaan Muallaf}

Manado selama ini dikenal dengan kota yang rukun dan damai dari segala aspek. Toleransi beragama pun berjalan mulus seolah tanpa cela. Nyaris tidak pernah terdengar terjadi konflik di daerah ini akibat agama. Bahkan, hasil penelitian Tim Kehidupan Balai Litbang Agama Makassar pada 2011 tentang Indeks Kerukunan Umat Beragama di Sulawesi Utara, menyebutkan kalau Manado masuk katetori Sangat Bagus (0,75 persen). Meski begitu, untuk menjadi seorang muallaf tampaknya tidak selamanya berjalan mulus. Seperti inilah dialami Delfi Elias, Pegawai Negeri Sipil Dinas Pariwisata dan Kebudayaan Kota Bitung. Menurut Faisal A. Sabaya, selaku saksi pertama pengislaman perempuan kelahiran Poigar, 19 April 1978 ini, Delfi mendapat larangan keras dari instansinya. Bahkan, Delfi yang mengucapkan syahadat di Masjid AlMunawarah, Mahawu, Tuminting, Manado, 25 Juni 2012 ini, dilarang oleh atasannya mengikuti pendidikan dan latihan (diklat) PIM lantaran ketahuan pindah agama. Meski begitu, Delfi tetap bersikukuh mempertahankan agama barunya itu (Islam). Larangan memilih agama dan keyakinan ini tentu saja bertentangan dengan UUD 1945 pasal 29 ayat 2 tentang kebebasan memeluk agama.

\section{Kemenag Belum Memperhatikan Muallaf}

Pembinaan muallaf ternyata belum mendapat perhatian serius dari pihak kementerian agama, baik di tingkat provinsi maupun di kota. Buktinya, selain tidak memiliki data-data mengenai berapa jumlah muallaf yang ada di daerahnya, kemenag juga tidak mengetahui secara pasti tentang bagaimana bentuk pembinaannya. Kemenag sepertinya mempercayakan atau menyerahkan sepenuhnya kepada pihak lain, dalam hal ini lembaga-lembaga keagamaan dan individual, yang sejauh ini sudah berjalan cukup bagus menurut perkiraan pemerintah. Kemenag sebenarnya pernah mempunyai program khusus menyangkut pembinaan umat Islam. Namanya, Lembaga Pendidikan Pengamalan Agama Islam (LP2A). Sayang, program dari pusat ini terpaksa berhenti di tengah jalan lantaran terbentur masalah klasik; dana! 
Belum adanya perhatian darikemenag provinsi dan kota, mendapat kritikan tajam dari Ketua KWI Manado, Sartje Rachim Mokoginta. Menurutnya, seharusnya kemenag yang turun langsung membina muallaf. Sejauh ini, mereka yang melakukan pembinaan berjalan sendiri-sendiri dalam membina masing-masing jamaahnya. Mereka sama sekali tidak bekerja sama dengan kemenag secara institusi. Artinya, mereka sendiri yang membina, membuat sendiri kurikulum pengajaran, dan sebagainya.

Kembali ke soal belum adanya data resmi jumlah muallaf yang dibina itu, ternyata diakui pula oleh yang lain. Misalnya Sartje Rachim Mokoginta, Rukimina, Faisal A. Sabaya, dan KH. Wahab. Mereka memang biasa mencatat nama anggota baru, terutama muallaf. Hanya, mereka tidak menyimpannya sebagai arsip. Apalagi, terkadang, ada orang-orang yang keluar masuk, sehingga mereka kesulitan mendatanya terus menerus. Selain itu, fokus mereka memang adalah melakukan pembinaan. Jadi, setelah dilakukan pengislaman atau ketika ada yang merekomendasikan muallaf untuk dibina, mereka langsung menerimanya dan memasukkan ke dalam kelompok binaannya. Baginya, administrasi itu tidak terlalu penting karena tujuan utamanya adalah mengajarkan AlQuran dan pengetahuan Islam di kalangan orangorang Islam maupun muallaf.

Beruntung, ada orang-orang yang begitu peduli terhadap nasib muallaf dan kemudian ingin membinanya secara serius tanpa harus menunggu lampu hijau dari pihak kemenag. Mereka inilah yang kelihatan cukup intensif melakukan pembinaan sampai sekarang ini. Namun, untuk mendapatkan data-data muallaf dalam bentuk tertulis atau pembukuan, ternyata sangatlah sulit. Bahkan, tidak ada! Data-data itu sebenarnya ada di setiap Kantor Urusan Agama (KUA). Setelah diislamkan, mereka lalu dibuatkan sertifikat oleh imam masjid (tempat pengucapan syahadat), dan sertifikat ini kemudian diserahkan ke KUA, yang menyatakan bahwa orang itu telah memeluk Islam. Setidaknya, apabila ada yang ingin menikah (terutama muallaf), mereka diharuskan menyertakan sertifikat keislamannya ke KUA.

Sayangnya, dalam hal ini, KUA hanya mendaftarkan orang bersangkutan (yang mau menikah) tetapi tidak mencatatkan namanya dalam bentuk arsip. Padahal, jika dihitung-hitung, jumlah orang yang akan melangsungkan pernikahan setiap tahun itu cukup banyak, yakni berkisar 20 sampai 30 orang. Dan kalau ini dikaitkan dengan statistik pemeluk agama Islam di Kota Manado, tentu saja jumlahnya akan terus bertambah setiap tahun. Kuat dugaan, bertambahnya jumlah penganut agama Islam yang tercatat di kemenag itu, hanya disebabkan oleh angka kelahiran, bukan konversi.

Setali tiga uang. Orang-orang yang melakukan pembinaan muallaf juga tidak menganggap pencatatan administrasi itu bagian penting. Hampir tidak ada yang mengetahui secara pasti jumlah muallaf yang mereka bina, selain hanya mendugaduga angkanya saja.

\section{PENUTUP}

Kemenag sendiri belum memperhatikan pembinaan muallaf. Selain tidak memberikan bantuan dana, kemenag juga tidak terlibat dengan pembinaan. Malah, kemenag tidak memiliki datadata terkait jumlah muallaf.

Yang melatari seseorang melakukan konversi ke Islam di Manado adalah pernikahan dan proses belajar. Namun, kebanyakan dari mereka itu memilih masuk Islam karena menikah. Umumnya perempuan. Pembinaan muallaf dilakukan oleh lembaga keagamaan Islam dan individual. Lembaga keagamaan/organisasi Islam itu adalah Kerukunan Wanita Islam (KWI) Manado, Yayasan Assalam (majelis taklim, KAKAP, dan Barisan Pemuda An$\mathrm{Nahl}$ ), serta individual yang dilakukan $\mathrm{H}$ Abdul Wahab Abdul Gafur. Model pembinaan dibagi atas tiga tahap, yakni mengaji, tata cara shalat dan bacaannya, dan pengetahuan agama. Jadwal pembinaan bervariasi; enam hari berturut-turut, tiga kali sepekan, dua kali sepekan, dan sekali sepekan. Sedangkan, pembinaan dilakukan di masjid, sekolah, dari rumah ke rumah, dan rumah pribadi.

Secara khusus, pembinaan muallaf belum ada. Para muallaf digabung dengan orang-orang muslim (yang juga belajar agama), serta dimasukkan ke dalam kelompok-kelompok berdasarkan pola pengajaran dan kemampuannya.

Hambatan-hambatan pembinaan muallaf adalah secara ekonomi dan kultural. Secara ekonomi, belum adanya bantuan dana dari pemerintah setempat, dalam hal ini kemenag provinsi dan kota. Kalaupun bisa tetap survive hingga kini karena 
kehadiran para donatur tetap dan tidak tetap, serta swadaya dari para jamaah.

\section{UCAPAN TERIMA KASIH}

Penelitian ini dibiayai oleh DIPA Balai Litbang Agama Makassar pada 2012. Peneliti mengucapkan terima kasih jajaran redaksi Jurnal Al-Qalam Balai Litbang Agama Makassar yang bersedia menerbitkan naskah ini. Untuk informan, antara lain, $\mathrm{KH}$ Abdul Wahab Abdul Gafur, Hj. Rukmina, Faisal. A. Sabaya, dan Hj. S. Rachim Mokoginta, peneliti juga mengucapkan terima kasih karena di tengah kesibukannya masih sempat meluangkan waktu meladeni peneliti. Juga, peneliti mengucapkan terima kasih kepada informan lain yang tidak disebutkan namanya di sini.

\section{DAFTAR PUSTAKA}

Badan Pusat Statistik Kota Manado. 2011.

Endraswara, Suwardi. 2006. Metode, Teori, Teknik Penelitian Kebudayaan.
Ideologi, Epistemologi, dan Aplikasi. Pustaka Widyatama. Yogyakarta.

Jalaluddin. 2001. Psikologi Agama. Jakarta : PT Raja Grafindo Persada.

James, William.. 2004.The Varietes of Religious Experience; Perjumpaan dengan TuhanRagam Pengalaman Religius Manusia. Penerjemah: Admiranto, Gunaean. Bandung : Mizan Media Utama

Moleong, Lexy J. 2010. Metodologi Penelitian Kualitatif. Edisi Revisi. Cetakan ke-28. Remaja Rosdakarya. Bandung.

Mulyono, Ninin Kholida. 2007. Proses Pencarian Identitas Diri pada

Remaja Muallaf (Studi Kualitatif Fenomenologis). Skripsi. Program Studi Psikologi Fakultas Kedokteran. Universitas Diponegoro. Semarang.

Paloutzian, Raymond F. 1996. Invitation to the Psychology of Religion. London:

Allyn and Bacon.

Pargament, K. I. 1997. The Psychology of Religion and Coping. New York: The

Guilford Press. 